\title{
Case Studies In Introductory Courses
}

\author{
Shele Bannon, CUNY Queensborough Community College, USA
}

\begin{abstract}
The introductory college classroom is the foundation of the learning process. It is a student's first exposure to the subject. These courses are strong in basic concepts, but often inadequate in developing essential critical thinking and problem solving skills, required in the $21^{\text {st }}$ century workplace. This article discusses the steps required to offer adaptions of existing case studies in an introductory course resulting in an enriched learning community. First, we suggest strategies to overcome the challenges inherent in the incorporation of this pedagogy for introductory students. Then, we present a step-by-step approach for the adaption of existing case studies to fit the learning objectives of the introductory course as well as the skill set of your students. Next is the discussion of the setting of ground rules to establish expectations, encouraging a community of trust, and recommended methods for a purposeful discussion. Finally, we address assessment of the process, which leads to mastering the art of case study teaching.
\end{abstract}

Keywords: Introductory Courses; Case Studies; Critical Thinking; $21^{\text {st }}$ Century Skills

\section{INTRODUCTION}

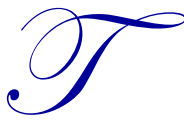

his is an exciting time in college education. Introductory courses, a student's first exposure to a subject, are strong in basic concepts, but are often inadequate in developing essential critical thinking and problem solving skills. In response, the American Graduate Initiative is funding grants over the next ten years to encourage innovative pedagogy in community colleges to prepare students for $21^{\text {st }}$ Century careers, which require graduates to perform complicated tasks requiring professional judgment and the ability to think critically about an issue (Grant Thornton, 2010) Requiring students to apply their academic knowledge to real world situations such as case studies, can meet this challenge (Coldwell \& Rose, 2006). Case study pedagogy offers educators an opportunity to develop these necessary skills through assignments that have more than one correct answer (Eyler, 2009). Case studies are situations involving a decision to be made or a problem to be solved. They provide practice and use of professional judgment in making decisions. Students understand the benefits they gain from this approach as reflected in the following comment from a student in one of my courses:

"The accounting skills will absolutely be practical for my career whether I decide to start my first job as a small business owner or as a broker. This case helps me to know how to use the skills we learn in the book and apply to the actual company. We had a better understanding of the numbers we crunch and a wiser decision will be expected when we do our real business."

This article discusses the steps required to offer adaptations of existing case studies in an introductory course resulting in an enriched learning community. First, I will suggest strategies to overcome the challenges inherent in the incorporation of this pedagogy for introductory level students. Then I will provide a step-by-step approach for the adaption of existing case studies to fit the learning objectives of the introductory course as well as the skill set of your students. Next, I discuss the setting of ground rules to establish expectations, encouraging a community of trust, and recommended methods for a purposeful discussion. Finally, I discuss how reflection and assessment of the process leads to mastering the art of case study teaching.

\section{CASE STUDY PEDAGOGY}

Critical thinking is inexorably linked with factual knowledge. Retrieving facts from memory and applying them in a new way is when thinking occurs. Robert Marzano (2011) says that critical thinking encompasses "habits 
of mind." Cases require learners to make assumptions, be open-minded, assess the accuracy of data, have an opinion, and to objectively analyze the risks (Bers, 2005). Case studies, therefore, intellectually challenge students by asking students to analyze, interpret, evaluate, infer, reflect, and make decisions. This application of knowledge is retained far longer than memorization of facts. Learning becomes experiential, deepening their understanding of the technical content, its use, and its value (Wilkin \& Collier, 2009).

Case study pedagogy in introductory courses is challenging for both faculty and students. Professors, while holding students to high expectations need to remain cognizant of the learning curve. Providing encouragement and support while challenging them to discover solutions for themselves will result in the most desired learning outcomes. Students, whose primary academic experience has been that of listening and note taking, will find the case method very different. After some initial hesitancy, they soon respond enthusiastically as they actively participate in their learning and begin to think for themselves. Most students are ready and able to think critically. However, faculty will need to challenge students to actively engage in this valuable pedagogy. Let students know early on that they are expected to become a purposeful critical thinker. The more students are actively engaged with the subject matter, the better they master the material and develop analytic reasoning skills (Chickering \& Gamson, 1987).

While case studies provide many advantages for student learning, they require careful planning and execution. Utilizing the case method in introductory courses entails a continual process of trial and error.

\section{ADAPTION OF EXISTING CASES}

There is a wealth of great cases for students. Sources such as Journal of Business Case Studies, Harvard Business Review, Richard Ivey Business School, Stanford University, and Darden Business Publishing, are an excellent beginning. The challenge is that these cases have been developed for senior level undergraduate as well as graduate students with a higher level of knowledge and skills. Start with the basic topics that might align with your course learning objectives. You will need to begin to modify the case to fit the current skills and knowledge level of your students. Cases that are student favorites continue to be modified each semester. Following are the steps required to adapt an existing case (Garvin, 2009).

1. Shorten the length of the case. Starting with a shorter case helps with this process. Usually students in introductory courses can manage about five pages of actual case material. Pages are added for detailed requirements. Financial information is added as exhibits. This is usually in the form of an excel worksheet.

2. Revise the technical information to your students' skill level. It is helpful to have a brief review of any calculations in the class before the case discussion as a whole. This allows students to all be on the same page during the discussion.

3. Key for student learning is the development of a set of reading questions. These questions guide students to the key points you want them to obtain as they read the case.

4. Adjust and clarify the requirements. This is crucial to getting the best outcomes. The more specifically you state what you want them to calculate, analyze, and decide, the better the results. Let students know they are required to support their answers with knowledge learned in class as well as data from the case. Be very specific as to what you want students to focus on. This is essential to their success.

5. Turn your case learning objectives into discussion areas allowing students to focus on the main themes. Themes include topics, areas of analysis, and decisions. Next develop key questions that will focus the discussion on these themes.

Examples of adapted cases personally used in my accounting courses, include topics such as estimating the allowance for doubtful accounts, importance of cash flows, selecting the best inventory valuation method, and a recently developed case that runs through several chapters relating to methods of raising money through the choice of partnerships, stock issues, or debt (Exhibit 1). Each case includes not only the technical aspects but also, more importantly, how this information is used to make real world decisions. Technical aspects include calculations, lab work, or research of a particular topic. Once they have mastered this content, then it is essential to ask the hard questions. What does this information mean? How can this information be utilized to help solve a particular problem? Is further research required? What is the best ethical choice? As students develop the skills to analyze 
information, they begin to form opinions as to the best decision for that company. As students work more cases through the semester, the improvement in their creativity and analysis of the issue at hand is dramatic. At this point the result will be a robust one hour class discussion. The best part is that students keep discussing the case as they are walking out the door.

\title{
EXHIBIT 1 - JET AMERICA: FINANCING CASE STUDY
}

\author{
Adaption of Jet Blue: Prepare for Financing, El-Hage, Payton, Smart, Copyright 2007 President and \\ Fellows of Harvard College.
}

\section{Learning Objectives}

1. Differentiate different forms of financing.

2. Identify the advantages and disadvantages of partnerships, corporations, and bond debentures.

3. Describe the impact to current ownership of each form of financing.

4. Contrast accounting for operating and capital leases.

Peter Hunt, Chief Financial Officer of Jet America Inc., looked up in the skies at John F. Kennedy's New York International Airport on a summer day in July 2013 and contemplated the company's fast growth and increasing debt. As he watched Jet America planes, he weighed the possibilities of how to raise the capital needed to fund future growth.

Since its launch in August 2007, Jet America has welcomed over eleven million guests. They have won many best-in-class travel industry awards since their launch, including most recently, winning Condé Nast Traveler's Reader's Choice Award for "Best Domestic Airline" for four consecutive years and Travel + Leisure World's Best Awards for "Best Domestic Airline" for four consecutive years. This was achieved by focusing on improving the flying experience for its customers. In addition to flying in new airplanes, Jet America has reliable on-time performance, comfortable and roomy leather seats, and the most advanced in-flight entertainment system. They also provide customers attractive fares for an upscale flying experience for less. The most pressing issue for Hunt was how to finance this rapid expansion and at the same time manage their large amount of debt (capital leases).

\section{History}

Year-over-year total revenue has grown at a rapid rate. In the past two years, Jet America increased their passenger capacity by $65 \%$. To accommodate this significant growth they expanded their fleet from 38 aircrafts in 2010 to 53 aircrafts today. Jet America financed its aircraft purchases through some operating leases but mostly capital leases that are secured by each plane. Would such financing continue to be available to the company? In the past year they have added service to six additional new cities making it a total of 20 cities serviced. In late 2012, Jet America completed a reservation system migration costing them between $\$ 10$ and $\$ 15$ million. While this system will provide a stable platform for the Company's growing operations in the long term, the transition limited free cash flow as well as profits.

Jet America is currently owned $25 \%$ by the original founder and $75 \%$ by a group of investors. Since the initial investment in 2007, Jet America raised an additional \$150 million from investors in 2011.

\section{Airline Industry}

The global airline industry continues to face challenges in 2013, from rising costs in fuel and economic uncertainties. The industry is characterized by intense competition and strong buyer power (fare wars by airlines) that leads to low profit margins. In the past decade, the airline industry has been attacked by economic and regulatory changes, causing many to declare bankruptcy, consolidate, or even leave the market. Two mergers include Delta's purchase of Northwest and United combining with Continental. Recently American Airlines merged with US Airways. This consolidation has been shifting pricing power back to the airlines. 
The Federal Aviation Administration (FAA) projects the demand for air travel will double over the next 20 years. Passenger demand is growing at a rate of 6\% in 2013 and about 5\% in future years. However, government regulation continues to increase costs. Emission surcharges, new pilot fatigue rules possibly causing a pilot shortage, as well as oil production impacted by political tensions in the Gulf. Additionally, the Department of Transportation requires all airlines to quote ticket prices including taxes and fees.

A significant risk to airline profits is fuel prices, which runs approximately $30 \%$ of revenue. The good news is that the U.S. Energy Information Agency forecasts lower petroleum prices from \$94/barrel in 2012 to \$93/barrel in 2013. Airlines need to figure out ways to counter rising fuel expenses. One strategy used by Jet America is to purchase more efficient aircraft. Fuel prices are beyond the control of the airlines. Passing the increased cost on to customers in the form of fare hikes seems an effective solution. In the past two years, airlines imposed hefty fare increases, primarily due to the recent mergers.

\section{Financial Results}

Despite difficult industry dynamics, Jet America posted strong revenue growth between 2007 and 2012. At the end of their second quarter (six months) results for 2013 reported an operating loss of $\$ 37$ million on revenues of $\$ 610$ million. The CEO of Jet America said, "Jet America needs a track record of profitability. Our primary financial goal is to make money consistently and generate acceptable returns. I believe our profit situation will change thanks to big revenue gains, the maturing of existing markets, a commitment to slower growth that includes no new aircraft deliveries until 2015 and a new agreement with investors to restructure our debt."

In May 2013, Jet America was able to modify terms with some creditors, which eliminated $\$ 250$ million of debt and cut interest expense. However, they borrowed an additional \$75 million in April 2013.

\section{Financing Alternatives}

Jet America's expansion required cash for new aircraft and internal reservation systems. As a result of their cash shortage, they have paused their growth by not adding additional aircraft until 2015 . Revenue growth has been achieved by increased capacity on each flight. Hunt needs to decide how to raise additional capital to fund the company's continued growth and depleting cash flow. This can come form a partnership, an IPO, or the issuance of a bond to raise the necessary capital. He is considering a possible partnership with another airline or a possible joint venture with a fuel supplier. He needs to make his recommendation to the board.

Beyond the need to finance its expansion into new markets, Hunt believed that there were other reasons to raise additional capital. First, new capital would ease Jet America's ability to finance its short-term obligations. Jet America does not have a line of credit, or a short term borrowing facility, and therefore depends on operating cash flow to service its lease obligations and to finance their operating losses. Secondly, additional capital would strengthen the company's balance sheet at a time when Jet America is shouldering a significant amount of debt related to new aircraft purchases (capital leases) and dwindling equity. Third, Hunt is thinking of further repayment of the debt or leases on his current aircraft contributing to healthier liquidity ratios.

\section{Partnerships}

As many other airlines have done, they could merge into a partnership with another airline. This would provide economies of scale by combining administrative functions, thus reducing overall costs of the combined airline. Additionally, they could pursue a partnership outside of the airline industry. One option is to partner with a major supplier (fuel) and another option would be to partner with a company that could contribute much needed capital to the company.

\section{Leasing}

It was Jet America's policy to finance its aircraft through either operating or financing leases. As of June 2013, the company held operating leases on 14 aircraft and owned the fleet's remaining 39 aircraft, which were 
financed through financing leases. Will Jet America be able to continue financing aircraft through leases? Would they be able to obtain the financing? You will need to look at these factors from the point of view of the lender.

\section{Stock Offering}

When considering whether to raise equity capital, Hunt knew that he would have to determine whether the stock price was reasonable. To aid in his analysis, Hunt assembled a financial forecast for Jet America. Hunt generally favored a conservative capital structure or a low debt to equity ratio that would help to ensure Jet America's financial flexibility, access to capital, and favorable lending rates. However, he knew that the company's board of directors would be extremely sensitive about the dilution that an equity offering would cause to existing owners.

\section{Bond Issuance}

Hunt then turned to the bond option. Jet America's investment bankers had recently proposed a placement of debt that would be unsecured. The debt offering would provide the needed capital at relatively low interest rates. In addition, raising new debt would be seen as a more attractive option than the equity offering by the board members who were particularly concerned about dilution. Should Jet America increase their debt? What would the impact be to obtaining additional financing, if needed?

\section{Reading Questions}

1. Who owns Jet America?

2. Why do they need to obtain financing?

3. What are the concerns of the airline industry?

4. What are Jet America's concerns?

5. What are their financing options?

\section{Discussion Questions}

Jet America is a new airline. The business was started six years ago, and has grown rapidly since inception. Jet America is incurring losses and a dwindling cash balance. As he thought about the alternatives, Hunt's mind wandered to the pros and cons of each option.

\section{Part I-Partnerships}

1. What are the advantages and disadvantages of forming a partnership?

2. Why would it be beneficial to partner with a supplier? Or another airline? Is another partner more advantageous? Why?

3. What are the key items that should be included in the partnership agreement? Be specific.
a. Ownership percentages
b. How much capital should be required by new partner?
c. Income/Loss formula
d. Terms of liquidation

Part II - Equity

1. Looking at the Equity Section of Jet America's balance sheet, discuss what their current equity reflects about the company. Discuss the capital and retained earnings separately.

2. Based on the current ownership, what percentage of the company should be sold in the stock offering? How does this dilution of ownership impact the current owners? Support your percentage with calculations and facts from the case.

3. What type of stock should they offer? Why? What is the impact to the company? 
4. What are the stock prices of other airline company's? (Research the actual stock prices to compare with the offering price for Jet America) What do you think is a realistic stock price? Discuss all the factors that determine market value of stock in relation to Jet America, as well as all companies.

Part III - Bonds

1. Discuss at least two possible types of bonds that Jet America could offer. Include the pros and cons of each option.

2. What is the impact to Jet America's net income and cash flow after issuing the bond? Include calculations and explanations of your conclusion.

3. What are the current market conditions for "A" rated companies? Based on the terms of the bond issuance - will the bonds sell for a premium or a discount? (Research current bond rates and determine if the market rate is above or below the stated rate)

4. Discuss Jet America's leases. They have both operating and financing leases. By looking at the financial information, how do they both impact net income and cash flow?

5. What is the current position of the International Financial Reporting Standards (IFRS) on leases? (Research IFRS and Leases - see link to start: http://www.ifrs.org/Current+Projects/IASB+Projects/Leases/ Leases.htm)

\section{Conclusion}

1) What are the options available for Hunt to raise capital? Are there any other reasonable options not noted in the case? Be creative and practical at the same time. Discuss at least three advantages and disadvantages for each of the options. Use the information you calculated and discussed above to support your statements.

a. Impact to net income and cash flow

b. Impact to debt ratios

c. Interest rates

d. Dilution of current ownership

e. Partnership agreement key points

2) What is your conclusion as to the best decision for Jet America? Support your decision. Select one of the options you noted above. Explain why it is the best choice for Jet America. (This should be at least several paragraphs)

Jet America Case has financial statement exhibits - not included.

\section{SET THE STAGE - GROUND RULES}

You will need to prepare your students for a class that will be different from what they have experienced in the past. Take the first weeks to get to know your students. Knowing their names will help provide an opportunity to demonstrate your belief and confidence in their abilities (Ellet, 2007). Hand out the case several classes before your discussion. This is a good time to set the ground rules of a mutual respect of the learning process.

1. Instructor and students need to be on-time, well-prepared, involved, and engaged in each case discussion.

2. Students must take responsibility for their own discovery.

3. Instructor and students must make a serious effort to take risks and be open to all views.

Explain how you, the instructor may do more listening than talking; and that students are encouraged to not only ask questions but to also respond to other students. As the instructor, you will need to prepare for both the content and the process. By demonstrating a strong commitment to preparation, students will learn to match your level of preparation (Kahu, 2013). Critical to a successful class discussion is the role of the teacher. The best results will be achieved if the discussion leader is guiding rather than controlling. Teaching is encouraging discovery. Guiding allows students to own the discussion and their learning. The role of the instructor as listener is a critical element in establishing student ownership. Instructors should limit their own comments opting instead to listen carefully to each comment. Students who feel secure and supported by the instructor often lead to the best contributions. 
Based on personal experience, case discussion teaching is definitely an acquired art that requires considerable practice. The instructor is required to ask appropriate questions, listen carefully, respond constructively and timely, deal with uncertainty, and create a learning environment of openness and trust. They are the planner, moderator, host, judge, and devil's advocate. That is the challenge. The reward is the satisfaction of true intellectual collaboration, energized discussions, deeper learning, and students who can articulate and develop critical insights.

\section{THE DISCUSSION}

All students should be expected to have a plan of action for the main character in the case. A fun way to start is by asking the class to vote as to their best option for the case. You're opening question can then ask why they are committed to their recommendation. For example in the Jet America case, you can ask, "Why is issuing stock the best financing choice for Jet America?" The first question is the most important, because it anticipates where the discussion will take you. This question can also prompt identification of the problem or a debate. You want to pose questions that encourage students to use the information in the case to define the problem. Then you can transition to generating many alternative solutions. Challenge students to support their answers with reasoned arguments.

Understanding your students helps you to know who to call on. If the same students are dominating the discussion, you can turn your back or hold up your hand to let other students have a turn. You can encourage other students to speak by simply making eye contact or walking toward a student. If you have a group of shy students, you can provide small group time before the whole class discussion. This usually provides a warm up to the discussion raising the confidence level of those students. You can respond to a student's comments directly or stimulate student-to-student discussion by asking another student to answer. Last, but certainly not least, is the impact of listening and waiting. Give students time to think. Silence is a normal part of the process. If an instructor answers their own questions with insufficient wait time, students will stop thinking for themselves.

\section{TOOLS FOR CLASS DISCUSSION}

The board, (black or white) is the key tool for the discussion. Document each student discussion point on the blackboard allowing students to review what has been said. Sketching out ahead of time the main points you want to see outlined on the board can act as a template to help you guide the discussion. The board is passive, it can be used to list and prioritize topics. Highlighting particular comments, signals that it's not only a point to remember but also important student feedback. You can draw circles or lines to emphasize a point or link ideas together (Garvin, 2009).

\section{REFLECTION AND ASSESSMENT}

Leave at least five minutes at the end of the class discussion to reflect on what has been learned. Either the instructor or a student can summarize the key points and draw links to the content in the course. For the past several years, I have been asking students to write reflections on their experience with the use of case studies. Here are just a few:

"After finishing this assignment it became apparent to me that in order for me to generate a smart business decision it is important to weigh the views of all the parties affected by this decision because if not, the option may not even be used at all."

"The completion of this case will help me in my future work career. In this course, I learned that the connections between financing and accounting are significant. In order to succeed in the business world, I have to recognize the connections and make use of them."

"Altogether, they have helped me improve my analytical and problem solving skills, I am now able to better understand the economic related problems, and the factors of any company and use my skills to attempt to solve these problems." 
I have found several approaches to assessing student learning through case studies. First, I have developed a rubric to help assess each student's contribution to the discussion. Students tend to do what you plan to measure. Let students know how they will be graded on participation, preparation, knowledge of facts, and the ability to form reasoned arguments (See Exhibit 2). Second, I have included questions from the case on the next exam to reinforce their ability to make judgments supported by facts. Last, is to have each student write a short essay on an assigned case to assess their ability to develop and analyze their own ideas.

Exhibit 2 - Rubric to Assess Student Learning for Case Study

\begin{tabular}{|c|c|c|c|c|c|}
\hline Component & $\underline{4}$ & $\underline{\mathbf{3}}$ & $\underline{\mathbf{2}}$ & $\underline{1}$ & $\underline{\mathbf{0}}$ \\
\hline Identifies and summarizes the problem/issue & $\begin{array}{l}\text { Clearly identifies issue and } \\
\text { summarized topic }\end{array}$ & $\begin{array}{l}\text { Identifies issue and summarized } \\
\text { topic }\end{array}$ & $\begin{array}{l}\text { Partially identifies issue and } \\
\text { briefly summarized topic }\end{array}$ & $\begin{array}{l}\text { Identifies issue, inadequate } \\
\text { summary }\end{array}$ & $\begin{array}{l}\text { Did not identify or } \\
\text { summarize issue }\end{array}$ \\
\hline $\begin{array}{l}\text { Identifies specific supporting examples and } \\
\text { current laws and legislation }\end{array}$ & $\begin{array}{l}\text { Clearly identifies supporting } \\
\text { data related to topic }\end{array}$ & $\begin{array}{l}\text { Identifies supporting data } \\
\text { related to topic }\end{array}$ & $\begin{array}{l}\text { Partially identifies supporting } \\
\text { data }\end{array}$ & $\begin{array}{l}\text { Supporting data not related to } \\
\text { topic }\end{array}$ & $\begin{array}{l}\text { Did not find supporting } \\
\text { data }\end{array}$ \\
\hline $\begin{array}{l}\text { Demonstrates higher level thinking by } \\
\text { interpreting the conflict of interest for the } \\
\text { dilemma }\end{array}$ & $\begin{array}{l}\text { Well-documents evaluation of } \\
\text { all implications of the dilemma } \\
\text { and inherent conflicts of interest }\end{array}$ & $\begin{array}{l}\text { Evaluates some of the } \\
\text { implications inherent in the } \\
\text { conflict of interest }\end{array}$ & $\begin{array}{l}\text { Partially evaluates implications } \\
\text { inherent in the conflict of } \\
\text { interest }\end{array}$ & $\begin{array}{l}\text { States implications with no } \\
\text { evaluation of conflicts of } \\
\text { interest }\end{array}$ & $\begin{array}{l}\text { Does not evaluate } \\
\text { implications related to } \\
\text { the conflict of interest }\end{array}$ \\
\hline $\begin{array}{l}\text { Identifies implications, options, evaluates } \\
\text { conclusion and consequences and justifies } \\
\text { decision }\end{array}$ & $\begin{array}{l}\text { Accurately supports decision } \\
\text { with well-developed explanation }\end{array}$ & $\begin{array}{l}\text { Accurately supports decision } \\
\text { referencing most of required } \\
\text { criteria }\end{array}$ & $\begin{array}{l}\text { Supports decision with } 50 \% \text { of } \\
\text { required documentation }\end{array}$ & $\begin{array}{l}\text { Provides inaccurate or } \\
\text { insufficient information to } \\
\text { support decision }\end{array}$ & $\begin{array}{l}\text { Does not explain } \\
\text { rationale for decision. }\end{array}$ \\
\hline $\begin{array}{l}\text { Communicates clearly and effectively, using } \\
\text { appropriate conventions of language (e.g. } \\
\text { grammar, spelling, punctuation) }\end{array}$ & $\begin{array}{l}\text { Communicates with precision } \\
\text { and enhanced expression } \\
\text { through highly effective use of } \\
\text { vocabulary and sentence variety; } \\
\text { infrequent, if any lapses in use } \\
\text { of conventions. }\end{array}$ & $\begin{array}{l}\text { Communicates effectively } \\
\text { throughout the essay, with few } \\
\text { lapses in use of conventions }\end{array}$ & $\begin{array}{l}\text { Communicates clearly through } \\
\text { the essay; sentences may contain } \\
\text { some lapses in use of } \\
\text { conventions, but these rarely } \\
\text { impede comprehension. }\end{array}$ & $\begin{array}{l}\text { Communicates clearly at } \\
\text { times, showing some ability } \\
\text { to use conventions, but whole } \\
\text { sections are unclear or errors } \\
\text { frequently impede } \\
\text { comprehension }\end{array}$ & $\begin{array}{l}\text { Communicates little } \\
\text { because few sentences } \\
\text { demonstrate appropriate } \\
\text { use of conventions. }\end{array}$ \\
\hline $\begin{array}{l}\text { Participates in oral discussion demonstrating } \\
\text { critical and creative thought by producing } \\
\text { new arguments or solutions to complex } \\
\text { problems. }\end{array}$ & $\begin{array}{l}\text { Participates in discussion } \\
\text { demonstrating high levels of } \\
\text { creative thought by producing } 3 \\
\text { to } 5 \text { new arguments, solutions. }\end{array}$ & $\begin{array}{l}\text { Participates in discussion } \\
\text { demonstrating creative thought } \\
\text { by producing } 3 \text { to } 4 \text { new } \\
\text { arguments, solutions. }\end{array}$ & $\begin{array}{l}\text { Participates in discussion } \\
\text { demonstrating some levels of } \\
\text { creative thought by producing } 2 \\
\text { to } 3 \text { new arguments, solutions. }\end{array}$ & $\begin{array}{l}\text { Participates in discussion } \\
\text { demonstrating low levels of } \\
\text { creative thought by producing } \\
1 \text { to } 2 \text { new arguments, } \\
\text { solutions. }\end{array}$ & $\begin{array}{l}\text { Does not participate in } \\
\text { discussion. }\end{array}$ \\
\hline
\end{tabular}

\section{CONCLUSION}

The case method offers students an opportunity to participate actively in classroom learning. For the educator, this is a most satisfying undertaking because it offers the reward of seeing students apply knowledge in ways that clearly will enhance their careers. The case method does more than convey information; it teaches students the critical thinking processes while enhancing their confidence, motivation, and responsibility for their own learning. It reflects an educational belief that it's not enough to teach people to be technicians, it's important to teach them how to use the information they have learned.

"Since we live in an age of innovation, a practical education must prepare a man for work that does not yet exist and cannot yet be clearly defined." - Peter F. Drucker (The Drucker Exchange, 2013).

\section{AUTHOR INFORMATION}

Shele Bannon is currently an Assistant Professor at CUNY Queensborough Community College. Professor Bannon's teaching experience includes Marymount Manhattan College, St. John's University, and Fordham 
University. Prior to teaching, Professor Bannon had over 15 years of senior financial management positions in a variety of industries and is the recipient of the Hewlett, Sokol and CETL grants. Professor Bannon has presented at several academic conferences and published in the CPA Journal (2) and the Journal of CPA Practitioners. E-mail: sbannon@qcc.cuny.edu

\section{REFERENCES}

1. Bers, T. (2005). Critical thinking: Unfinished business. New Directions for Community Colleges, 130, 1525. doi:10.1002/cc.v2005:130/issuetoc

2. Chickering, A. W., \& Gamson, Z. F. (1987). Seven Principles for good practice in undergraduate education. American Association of Higher Education Bulletin, 39(7), 3-7. Retrieved from http://www.lonestar.edu/multimedia/SevenPrinciples.pdf

3. Coldwell, C. L., \& Rose, J. T. (2006). Teaching and application in introductory finance: Using an excelbased study as a pedagogical tool. Journal of Business Case Studies, 2(1), 23-28. Retrieved from http://journals.cluteonline.com/index.php/JBCS/article/view/4876/4969

4. $\quad$ Ellet, W. (2007). The case study handbook: How to read, discuss, and write persuasively about cases. Boston, MA: Harvard Business Review Press.

5. El-Hage, N. N., Payton, C. E. J., \& Smart, D. (2007). JetBlue: Prepare for financing. Boston, Ma: Presidents and Fellows of Harvard College. Retrieved from http://hbr.org/product/jetblue-prepare-forfinancing/an/207061-PDF-ENG

6. Eyler, J., Mosakowski Institute for Public Enterprise. (2009, March). Effective practice and experiential education. Paper presented at the Conference on Liberal Education and Effective Practice for Clark University and Association of American Colleges and Universities, Worcester, MA.

7. Garvin, D. A. (2009, June). Effective case discussion. Art and Craft of Discussion Leadership. Workshop conducted at Harvard Business School, Boston, MA.

8. Grant Thornton International Ltd. (2010). The evolving accounting talent profile: CFO Strategies for attracting, training, and retaining accounting professionals. Retrieved from http://www.grantthornton.com/ staticfles/GTCom/Grant\%20Thornton\%20Thinking/Whitepapers/Accounting\%20talent\%20WP/Accountin g\%20talent\%20-\%20FINAL.pdf

9. Kahu, E. R. (2013). Framing student engagement in higher education. Studies in Higher Education, 38(5), 758-773. doi:10.1080/03075079.2011.598505

10. Marzano, R. (2011). The art \& science of teaching. Alexandria, VA: ACSD.

11. The Drucker Exchange. (2013, July 30). Re: A problem to solve. Retrieved from http://thedx.druckerinstitute.com/2012/07/a-problem-to-solve/

12. Wilkin, C. L., \& Collier, P. A. (2009). Problem - based approach to accounting education: Pragmatic appraisal of a technologically enabled solution. International Journal of Education and Development Using Information and Communication Technology, 5(2), 49-67. Retrieved from http://ijedict.dec.uwi.edu/viewarticle.php?id=658 
NOTES 